BLS 34, No 1 2008. DOI: http://dx.doi.org/10.3765/bls.v34i1.3553

(published by the Berkeley Linguistics Society and the Linguistic Society of America)

\title{
A Semantic Analysis of the Wason Selection Task
}

\author{
JEANNE APTEKMAN \\ Lattice UMR 8094 (ENS, Centre National de la Recherche Scientifique)
}

\section{Introduction: Logic, Natural Language and the Psychology of Reasoning}

In introduction, we would like to focus on the distinction between three different levels: a logical relation, a (logical) formalization of this relation, and the way natural language expresses this relation. By analyzing the relations between these three levels, we would like to present the aims and the complexity of the psychology of reasoning's program.

\subsection{Logical Implication, Material Conditional and SI-Clauses}

Let us look at the following example:

Paris est la capitale de la France et Berlin la capitale de l'Allemagne, Paris is the capital of France and Berlin is the capital of Germany

From this sentence, everybody agrees to conclude with:

Donc, Paris est la capitale de la France. (Ou Donc Berlin est la capitale de l'Allemagne).

Then, Paris is the capital of France ( $O r$ Berlin is the capital of Germany)

In the same way, everybody agrees to accept as logically true the following conditional statement:

$$
\begin{aligned}
& \text { Si Paris est la capitale de la France et Berlin la capitale de } \\
& \text { l'Allemagne, } \\
& \text { Alors Paris est la capitale de la France. } \\
& \text { If Paris is the capital of France and Berlin is the capital of Germany, } \\
& \text { Then Paris is the capital of France. }
\end{aligned}
$$

Everybody seems to agree to say that (3) has to be understood as a true statement. 
Jeanne Aptekman

What allows us to recognize (3) as true does not depend on a specific formalization, nor on a definite logic. It is not necessary to be a trained logician to accept as true this statement. Both the naïve subject and the great mathematician would admit that we have a relation of logical entailment at work.

Moreover, we can see that this relation does not rely on what is specifically expressed in this example. We consider (2) as a logical consequence of (1) because of their logical form. Then, by keeping the same form in both the premise and the apodosis, we must get the same logical consequence relationship between them. So from any $A$ and $B$ statement, we can (or must) infer $A$ or $B$.

So from a relationship between two particular statements, we got to a relationship between two forms, and what justifies that anybody accepts (3) as true is its very form.

Then, what logic does is trying to express this consequence relation by determining which forms activate it. It is not about constructing this relation, but about characterizing it in using the form of the statements that activate it. For doing it, Classical Logic develops a connector called material conditional.

The logical approach is a vericonditional one, which means that it is interested in truth conditions. Material conditional is then defined by its truth table, which is the following:

\begin{tabular}{|l|l|l|}
\hline $\mathrm{P}$ & $\mathrm{Q}$ & $\mathrm{P} \supset \mathrm{Q}$ \\
\hline $\mathrm{V}$ & $\mathrm{V}$ & $\mathrm{V}$ \\
\hline $\mathrm{V}$ & $\mathrm{F}$ & $\mathrm{F}$ \\
\hline $\mathrm{F}$ & $\mathrm{V}$ & $\mathrm{V}$ \\
\hline $\mathrm{F}$ & $\mathrm{F}$ & $\mathrm{V}$ \\
\hline
\end{tabular}

This truth table is grounded on the idea that the truth of the premise has to be transmitted to the apodosis, so when P is true, Q has to be true as well, and the only case in which the conditional statement is considered to be false is then the one in which $\mathrm{P}$ is true and $\mathrm{Q}$ is not.

But, this truth table was built for material conditional, not for SI-clauses and IF-clauses.

So we have three different things:

- A logical relation of necessary entailment (logical implication)

- A formalization of this relation (material conditional)

- Natural language IF-Clauses

We think that the main epistemological problem that psychology of reasoning has to solve is confusion between these three levels. 


\subsection{Psychology of Reasoning}

There are two different aims for psychology of reasoning. The first one is to specify the relation between logic and reasoning by testing subjects' reasoning abilities. The second one, which is strongly related to the first one, is to examine the hypothesis of a mental $\operatorname{logic}^{1}$ that would be internal to the brain. The hypothesis of a Mental Logic claims that logic is no longer thought as a formalisation or as a characterization of external laws. On the contrary, these laws are supposed to be first and subjects are tested to check if their reasoning is really congruent with the formalization proposed by logic.

The weak one tries to determine whether or not ordinary conditionals in si..., alors or in if..., then correspond to material conditionals, which is to determine whether or not the way subjects understand expressions associated with logical implication ( $s i \ldots$ alors clauses) correspond to its characterization in terms of material conditionals.

On the contrary, the strong version tries to determine whether or not the subjects right in their understanding.

We consider that the second approach is irrelevant, since material conditionals and rules associated with them are not primitive: they have been built in order to express logical implication, but the ambiguity between these two different versions seems to be an impediment in the analysis that have been proposed to the results.

\section{Wason Selection Task (WST), 1966.}

\subsection{Presentation of the Task}

In its paradigmatic version, the Wason Selection task consists in presenting four cards to the subjects. Each card is known to have a letter on one side and a number on the other side. Two of these cards are presented to the subjects with the letter side up, and two with the number side up. The subjects can read the following inscriptions on the four cards: A, D, 7, and 8. They are told that the rule is: If there is an A on one side, there is a 7 on the other one and they are asked to determine which card(s) it is necessary and sufficient to turn over to judge whether the rule is true.

\footnotetext{
${ }^{1}$ See Braine, P. and O'Brien, D. 1998
} 
Jeanne Aptekman
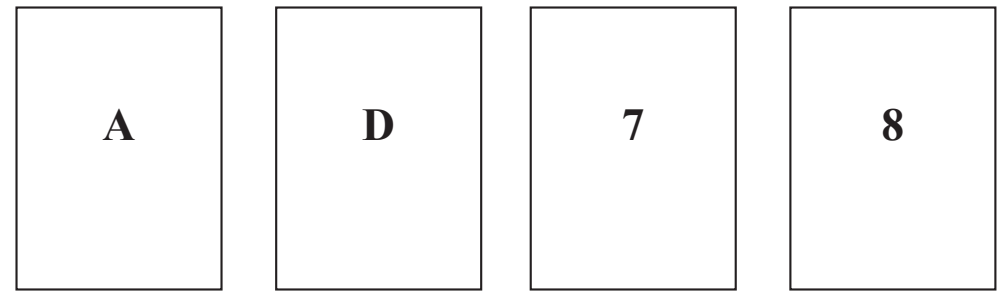

- Each card has a letter on one side and a number on the other side

- The subjects are told the rule: If there is an A on one side, there is a 7 on the other one

- Task: specify which card(s) it is necessary and sufficient to turn over to judge whether the rule is true.

The expected answers are the A-card and the 8-card, since if there were an A on the other side of the 8-card, it would falsify the rule. But, if most subjects decide to pick up the A-card $(P$ card $), 90 \%$ of them fail to choose the 8-card (Not- $Q$ card). Actually, more people choose to pick-up the 7-card ( $Q$ card)

The WST became famous because of these so-called bad results, and the question that arose was to understand why the subjects fail.

In order to answer this question, other versions have been proposed that were more familiar versions (Cosmides and Tooby 1992) or deontic versions (Griggs and Cox 1982).

But there are two different ways of understanding these results that corresponds to the two versions of the psychology of reasoning program for conditionals.

Then first way of understanding these results, which corresponds to the strong version of the program, would be to refute any logical ability to the subjects. It seems however unsatisfactory, since subjects do manifest logical abilities in everyday life, even if they are "logically naïve." Moreover, as we said, the material conditional has been built on the basis of what was recognized as true by everyone: thus the implication relation is a relation that subjects are able to perceive.

The second way is by postulating a gap between what the experimenter wants to test and what is actually tested. That would correspond to the weak version. If we agree to this understanding, as we do, we now have to determine what is actually tested in this task.

The first answer to this question is given by Sperber, Cara and Girotto (1995), and their relevance explanation of the tasks and its results. 


\subsection{A Pragmatic Analysis of the Wason Selection Task}

Sperber, Cara and Girotto (1999) propose a pragmatic analysis of the Wason selection task using relevance principles. This analysis is grounded on five hypotheses:

- Subjects understand the task as one of selecting potentially relevant evidence for evaluating the truth of the rule.

- Subjects envisage evaluating the rule in the only possible way, that is, indirectly, through its observationally testable consequences.

- Inferring some of the consequences of any statement is done spontaneously, as part of the process of comprehension, in order to arrive at relevant-as-expected interpretation.

- Subjects trust their intuitions, that is the output of their spontaneous inferential abilities; they take the directly testable consequences that they have inferred to be the consequences through which the rule should be tested.

- Subjects select the cards the observation of which may directly test these spontaneously derived consequences (Sperber, Cara and Girotto 1999)

By applying these principles, it seems natural to pick the A-card, and possibly the 7-card. Using their hypothesis, Sperber, Cara and Girotto set up easy experiments that respect the general rules of the Wason selection task and that are answered successfully by the subjects. So what Sperber et al. tell us is that this task is not testing the subjects' abilities to understand and apply conditional statements, at least as they are understood by classical logic.

However, the rule in the Wason Selection Task is formulated as a conditional statement (If $P$ then $Q / S i P$, alors $Q$ ), which is generally understood as corresponding to material implication. We are going to examine what it could teach us about the meaning of IF.

\subsection{What do the WST's Results Tell Us about the Meaning of If?}

We have seen that the task does not test the ability of understanding and applying conditionals. The subjects do not understand this task as a reasoning task, and depend on their intuitions to solve he problem, while experimenters would like subjects to rebuild the truth table of material implication. But this aim depends on the assumption that material implication and its "translation" in natural language (If...then / Si...alors statements) do coincide, which does not seem to be the case. The Wason selection task tests the subjects' understanding of If...then / Si ...alors statements, and shows us that this understanding differs from the one associated with material conditional.

Thus, subjects are not wrong, and their answer help us specify the meaning of If $/ \mathrm{Si}$. That is the reason why we would like to introduce now our semantic analysis of the Wason selection task. 
Jeanne Aptekman

\section{A Semantic Analysis of the Wason Selection Task}

We believe that the results can be explained in a very simple way: Subjects do what they are told to do. They understand the rule as an If (or Si)-clause, rather than as a material conditional. We base this interpretation on a study of SIclauses in French, which allows us to classify them into four classes of uses.

In order to introduce our semantic analysis of these results, we will now briefly present this classification ${ }^{2}$.

\subsection{A Study of $S I$-Clauses}

The classification we propose is made up with four classes of uses:

- $\quad$ The enunciative uses

- The hypothetical uses

- The concessive uses

- The comparative uses

The idea pertaining to this study is that the SI-clauses work as space constructors (Dancygier and Sweetser 2005), and we characterize the space set up by $S I$ as a transitory frame for the apodosis. In using this understanding of the $S I$ clauses, we can show how we can reinterpret the subjects' answers to the selection task as a proper understanding of the instructional meaning of SI, as well as a proper understanding of the instructional meaning of $I F$.

\subsection{Enunciative Uses: Discourse Conventions}

The enunciative uses work as discourse conventions set up in the protasis that make the enunciation of the apodosis possible. This possibility is an enunciative possibility: the protasis can provide either acceptability conditions for the apodosis (metalinguistic uses) or relevancy conditions (speech act uses).

\section{Metalinguistic comment on what is said:}

The first category of enunciative uses is the metalinguistic comments, which can concern:

- A single term in the apodosis, as in the following examples:

Faut-il signaler encore un pneu non pas increvable, mais qui se rit SI l'on peut dire - de la crevaison? (H. Tinard, L'Automobile) I consider this work, if you permit me, to be rather good.

- The whole apodosis:

Il manquait de conscience et, SI l'on excepte son amitié pour Robert, il n'avait pas de fidélité. (Georges Bataille, l'abbé C).

\footnotetext{
${ }^{2}$ for more details, see Aptekman 2008
} 
Such, unfortunately, is the case, if we except perhaps the admirable list of editions due to the great Panizzi (NY Times book review)

- A language convention

SI les transports publics sont la vie d'une ville, Vancouver est dans le coma.

If public transit is the lifeblood of a dynamic city, Vancouver is in a coma (cited in Dancygier \& Sweetser 2005)

\section{Speech act conditionals:}

SI tu as soif, il y a de la bière dans le frigo

If you're thirsty, there is beer in the fridge

\subsection{Hypothetic Uses}

We distinguish these enunciative uses from the hypothetic ones that involve cases in which the protasis activates (déclenche) the apodosis in a factual or in an inferential way. In the first case, we will talk about hypothetico-prospective uses, and in the second one, we would say that the uses are inferential.

\section{Hypothetico-prospective uses}

We call 'hypothetico-prospective' the uses that involve a notion of prediction, by presenting the protasis as potential.

Si je gagne au loto, j'achèterai une voiture / Si je gagnais au loto, j'achèterais une voiture

If I win the lottery, I'll buy a car / If I won the lottery, I'd buy a car

\section{Hypothetico-deductive conditionals and explicative uses: inferential uses}

We also consider as hypothetic some uses that are not prospective, but in which the protasis still activate the apodosis, even if it is not in a factual way.

We consider as hypothetico-deductive uses the uses that express a prediction that is neither temporal nor predictive (14), and the uses that are usually considered as explicative ${ }^{3}$ or epistemic ${ }^{4}$ ones (15 and 16).

(14) Ecoute, Antoine, tu diras tout ce que tu veux, moi je sors pas de là : SI tu obliques, tu vas pas tout droit! (Alain Robbe-Grillet, Les Gommes, 1952)

(15) If you turn right, you don't go straight

(16) S'il est riche, c'est qu'il a dû magouiller pas mal

\footnotetext{
${ }^{3}$ Cf. De Vogüe 1986.

${ }^{4}$ Cf. Dancygier et Sweetser 2005.
} 
Jeanne Aptekman

If he was running, he must have been guilty (Internet)

If ever there was a good Yankee, he must have been Irish (Internet)

\subsection{Concessive Uses: Non Efficient Cause and Limit Condition}

The third class of uses we distinguish gathers concessive uses. In such uses, what is expressed in the protasis allows what is expressed in the apodosis despite an implicit entailment (thwarted) that would assert If $P$, not $Q$.

In these uses the protasis sets up a frame in which the apodosis unexpectedly holds.

(19) Je n'ai le droit de le dire à personne, même SI au fond tout le monde s'en fout...

(20) SI Jake et Chuckie sont les personnages centraux du roman, ce serait faire injure à Mac Liam Wilson d'oublier la palette d'individus tous plus extravagants les uns que les autres. (Book review on the Internet) Toutefois, l'union - fruits, SI elle est en constantes relations avec le conseil supérieur de la conserve, a une gestion absolument indépendante.

(L'industrie des conserves en France, 1950)

(22) Even if something is not true, if it's repeated loudly and publicly enough, people tend to start believing the lie. (Internet website)

\subsection{Comparative Uses: Comparison Scale (specific to French)}

The last class we would like to introduce gathers the comparative uses that introduce a comparison between the protasis and the apodosis.

In these uses, the SI seems to connect the protasis and the apodosis without placing them in an inferential relation. So these uses are very different from the concessive ones since they d not refer to an implicit (thwarted) entailment. On the contrary, they put the two propositions in parallel, on a common scale.

In English, it could be translated by while:

$$
\begin{aligned}
& \text { SI Jean est adorable, Lucie est insupportable } \\
& \sim \text { While Jean was charming, Lucie was impossible }
\end{aligned}
$$

Je ne nie point que SI vingt métiers font la misère, vingt aventures font la solitude.

(Hervé Bazin, La Mort du petit cheval)

\section{Conclusion: SI Introduces a Transitory Frame for the Apodosis and Subjects Understand IF-Clauses in the WST}

In all these uses, we can consider SI as providing a frame for the apodosis, and this frame must be understood as transitory. This frame is built in the protasis in order to interpret the apodosis. 
Based on this hypothesis it is easy to reinterpret the WST's results: they appear to show that subjects d understand If/Si-clauses. Actually, almost all subjects pick up the A card, that is the frame $P$ card. By doing this, they set up a frame that corresponds to the one set up by the apodosis. Then a large part of them chooses to turn over the 7 card, which is the apodosis $Q$ card. They consider the apodosis within the protasis frame. So by choosing the $P$-card and the $Q$ card, subjects do exactly what SI-clauses tell us to do: they use P as a frame, and they consider what happens in this frame.

In this understanding, the 8-card (Not-Q card) is out of the protasis frame, and subjects have no reason to choose it. If/Si-clauses semantics does not allow subjects to pick up the Not-Q card.

\section{References}

Aptekman, J. 2008. Locutions En Si Et Marqueurs Dans La Protase: Indice Cotextuels et Compositionnalité. Corela 6(1). http://corela.edel.univpoitiers.fr/index.php?id=224.

Caron, J. 1992. Précis de Psycholinguistique. Paris: Presses Universitaires du France.

Comrie, B. 1986. Conditionals: A Typology. In E. C. Traugott, A. Ter Meulen, J. Snitzer Reilly, and C. A. Ferguson, On Conditionals, 77-99. Cambridge: Cambridge University Press.

Cornulier, B. 1985. Effets de Sens, Paris, Seuil.

Cosmides, L. 1989. The Logic Of Social Exchange: Has Natural Selection Shaped How Humans Reason? Studies with the Wason Selection Task. Cognition 31, 187-276.

Culioli, A. 1990. Pour Une Linguistique de L'énonciation. Opérations Et Représentations, Tome 1. Paris: Ophrys.

Culioli, A. 1999. Pour Une Linguistique de L'énonciation. Formalisation Et Opérations de Repérage, Tome 2. Paris: Ophrys.

Culioli, A. 1999. Pour Une Linguistique de L'énonciation. Domaine Notionnel, Tome 3. Paris: Ophrys.

Dancygier, B. 1988. Conditionals and Concessives, Papers and Studies in Cognitive Linguistics 24, 123-32.

Dancygier, B. 1993. Interpreting Conditionals: Time, Knowledge and Causation. Journal Of Pragmatics 19, 403-34.

Dancygier, B. 1998. Conditionals and Prediction: Time, Knowledge and Causation in Conditional Constructions. Cambridge Studies in Linguistics, 87. New York: Cambridge University Press.

Dancygier, B. and E. Sweetser. 2005. Mental Spaces in Grammar: Conditional Constructions. Cambridge Studies in Linguistics, 108. New York: Cambridge University Press. 
Jeanne Aptekman

Degand, L. and H. Pander Maat. 2003. A Contrastive Study of Dutch and French Causal Connectives on the Speaker Involvement Scale. In A. Verhagen and J. Van de Weijer, eds., Usage-based Approaches to Dutch: Lexicon, Grammar, Discourse. Utrecht: LOT, 175-199.

Degand, L. and H. Pander Maat. 1999. Scaling Causal Relations in Terms of Speaker Involvement. In Levels of Representation in Discourse, Working Notes of the International Workshop on Text Representation, 45-54. Edinburgh University.

Fauconnier G., and M. Turner. 1996. Blending as a Central Process Of Grammar. In A. Goldberg, ed., Conceptual Structure, Discourse, and Language, Stanford, CLSI.

Fauconnier, G. and E. Sweetser, eds., 1996. Space, Worlds and Grammar. Chicago: University Press Of Chicago.

Filippi, C. 1998. La Relation de Concession: Etude Contrastive de Though En Anglais Et de Bien Que, Même Si Et Encore Que En Français. Linguistique Contrastive Et Traduction 4. Paris: Ophrys.

Grice, H. P. 1957. Meaning. In Philosophical Review 66, 77-88.

Grice, H. P. 1975. Logic and Conversation. In P. Cole and J.L. Morgan, eds., Syntax and Semantics 3: Speech Acts. Vol. 3, 41-58. New York: Academic Press.

Griggs, R. A., and J. R. Cox. 1982. The Elusive Thematics Material Effect in Wason's Selection Task. British Journal Of Psychology 73, 407-420.

Lakoff, G. 1987. Women, Fire, and Dangerous Things: What Categories Reveal About the Mind. Chicago: University of Chicago Press.

Langacker, R. W. 1987. Foundations of Cognitive Grammar: Theoretical Prerequisites. Stanford: Stanford University Press.

Sperber, D., F. Cara, and V. Girotto. 1995. Relevance Theory Explains the Selection Task. In Cognition, 57: 31-95.

Sperber, D. and D. Wilson. 1989. La Pertinence : Communication et Cognition. Paris: Les Editions de Minuit.

Sweetser, E. 1996a. Reasoning, Mappings and Meta-Metaphorical Conditionals. In M. Shibatani and S. Thompson, eds., Grammatical Constructions: Their Form and Meaning. Oxford: Oxford University Press.

Sweetser, E. 1996b. Mental Spaces and the Grammar Of Conditional Constructions. In G. Fauconnier, G. and E. Sweetser, eds. Space, Worlds and Grammar. Chicago: University Press of Chicago.

Sweetser, E. 1997. Role and Individual Readings Of Change Predicates. In J. Nuyts and E. Pederson, eds., Language and Conceptualization. Oxford: Oxford University Press.

Talmy, L. 2000. Toward A Cognitive Semantics. Cambridge: Cambridge University Press.

Talmy, L. 2005. The Fundamental System of Spatial Schemas in Language. In D. B. Hampe and J. E. Grady, eds., From Perception To Meaning: Image Schemas in Cognitive Linguistics, 198-234. Berlin: Mouton de Gruyter. 


\title{
A Semantic Analysis of the Wason Selection Task
}

Victorri, B., and C. Fuchs. 1996. La Polysémie--Construction Dynamique Du Sens, Hermès.

Walliser, B., D. Zwirn, and H. Zwirn. 2005. Abductive Logics in A Belief Revision Framework. Journal of Logic, Language, and Information.

Wason, P. C. 1966. Reasoning. In B. M. Foss, ed. New Horizons in Psychology. Harmondsworth: Penguin.

\author{
Jean Aptekman \\ Lattice (UMR 8094) \\ 1 , rue Maurice Arnoux \\ 92120 Montrouge \\ France \\ jeanne.aptekman@gmail.com
}

